\title{
PROTECTION OF NORWEGIAN ORCHIDS- A REVIEW OF ACHIEVEMENTS AND CHALLENGES
}

\section{JØRN ERIK BJØRNDALEN}

\author{
Jens Bjelkesgate 16A, N-0562 Oslo, Norway \\ Corresponding author: jorn.bjorndalen@gmail.com
}

\section{ABSTRACT}

\begin{abstract}
Norway has a rich and diverse orchid flora consisting of 36 species. Orchids are found throughout the country, but most of the species are confined to calcareous or base-rich substrates. Important orchid-rich types of vegetation include rich pine and spruce forests, rich deciduous forests, open calcareous meadows, rocky outcrops and screes, hay meadows and calcareous mires and fens. Many species are rare, and 17 species and 3 subspecies are red listed. 13 species are generally protected. Both the orchids and their habitats are susceptible to various disturbances such as e.g. building activities, road construction, quarrying, drainage, forestry and changes in agricultural practices (less intense grazing, termination of mowing), which has resulted in the continuation of the previously inhibited succession. Most of the types of habitat mentioned are important conservation sites and thus many orchid occurrences (e.g. of Cypripedium calceolus, Epipogium aphyllum, Epipactis palustris and Ophrys insectifera) are protected by a network of nature reserves designated for these habitats. However, there is an urgent need to secure species with small populations in some of the mire reserves, and succession is also a problem in many of the reserves. Protection of the few existing localities for some species is also needed. A more detailed discussion of the status of the red listed species is presented.
\end{abstract}

Keywords: orchid conservation, nature reserves, management, orchid habitats, Norway

\section{Introduction}

Orchids are an important group of organisms associated with nature conservation in Norway, and especially spectacular and "charismatic" species such as e.g. Cypripedium calceolus, Ophrys insectifera and Cephalanthera rubra, are actively used for promoting nature conservation in various contexts (see e.g. Bjørndalen 2006). Many of the orchid-rich types of vegetation or nature described in the present paper have high conservation values because they are generally also habitats of high biodiversity (see e.g. Direktoratet for naturforvaltning 1999; Fremstad and Moen 2001; Lindgaard and Henriksen 2011).

Norway has a relative rich and diverse orchid flora, with occurrences all the way north to the northernmost county, Finnmark, and even in alpine areas. Most of the species are confined to calcareous or base-rich substrates and many species appear to be rare despite being widely distributed. The current edition of the Norwegian flora (Lid and Lid 2005) presents 36 species, including 2 subspecies. Eighteen hybrids are listed, some of them between different genera. One species is extinct, Liparis loeselii. Three additional subspecies have recently been distinguished and are on the current red list (Kålås et al. 2010). However, it is uncertain whether or not one of them, Gymnadenia conopsea ssp. densiflora, is a separate species, G. densiflora (Bjerke and Strann 2009). Dactylorhiza pseudocordigera was earlier regarded as a separate species, but is now included in D. lapponica (Wischmann and Norddal 1987; Lid and Lid 2005). A further discussion of the nomenclature of Orchidaceae presented in the latest edition of the Norwegian flora (Lid and Lid 2005) is given by Elven (2007). Hedrén et al. (2012) present a new classification of the taxa of Norwegian Dactylorhiza, which greatly differs from Lid and Lid (2005), but this discussion is beyond the scope of the present paper.

For comparison, 55 species of orchid are found in the entire Fennoscandian area (Mossberg and Stenberg 2003). Most of the additional species are confined to the limestone islands Öland and Gotland in the Baltic Sea, and Calypso bulbosa in northern Sweden occurs close to the Norwegian border.

Many of the orchids and their habitats are susceptible to a variety of negative effects such as e.g. urban development and building activities, road construction, quarrying, drainage of mires and wetland, forestry, changes in agricultural practices, such as e.g. less grazing and mowing, as a result of which succession occurs. Thirteen species are generally protected in Norway, and four additional species and three subspecies are red listed (Table 1).

The habitats became the most important issue for conservation in Norway after 1970 and the conservation of the important orchid-rich types of nature (e.g. mires, conifer forests and rich deciduous forests) has resulted in a comprehensive network of nature reserves and other conservation areas, which are also beneficial for both rare and more common species of orchids.

A more thorough treatment of the conservation status and assessment of how representative the protection is have been carried out only for a few species (e.g. through action plans for or special investigations of selected species, see below). This paper is the first attempt to present an overall review of orchid protection in Norway. This material was originally presented at the International Conference on Temperate Orchids (TORC'15) in Samos, Greece, in April 2015. 
Table 1 Protected and red listed orchid taxa in Norway, with IUCN annotation of their red list categories and rarity criteria based on the current red list (Kålås et al. 2010). Estimated fractions of the total European population of the taxa are taken from the fact sheets provided by the Norwegian Biodiversity Information Centre (http://www.artsdatabanken.no).

\begin{tabular}{|c|c|c|c|}
\hline Species/subspecies & Cat & Crit & Eur pop \\
\hline Liparis loeselii & RE & - & - \\
\hline Coeloglossum viride ssp. islandicum & $\mathrm{CR}$ & B & $<1 \%$ \\
\hline Herminium monorchis* & $\mathrm{CR}$ & B & $<1 \%$ \\
\hline Cephalanthera rubra* & EN & $B ; D$ & $<1 \%$ \\
\hline Dactylorhiza purpurella* & EN & $\mathrm{B} ; \mathrm{C}$ & $1-5 \%$ \\
\hline Epipactis palustris* & EN & $A ; B$ & $<1 \%$ \\
\hline Epipactis helleborine ssp. neerlandica & EN & $\mathrm{B} ; \mathrm{C}$ & $1-5 \%$ \\
\hline Lysiella oligantha* & EN & $\mathrm{D}$ & $>50 \%$ \\
\hline Microstylis monophyllos* & EN & $\mathrm{B} ; \mathrm{C}$ & $1-5 \%$ \\
\hline Nigritella nigra* & EN & B & $>50 \%$ \\
\hline Dactylorhiza sambucina* & VU & $A$ & $<1 \%$ \\
\hline Dactylorhiza traunsteineri & VU & A & $1-5 \%$ \\
\hline Gymnadenia conopsea ssp. densiflora & VU & $\mathrm{D}$ & $<1 \%$ \\
\hline Anacamptis morio* & NT & - & $<1 \%$ \\
\hline Cephalanthera longifolia* & NT & - & $1-5 \%$ \\
\hline Cypripedium calceolus* & NT & - & $1-5 \%$ \\
\hline Epipogium aphyllum* & NT & - & $1-5 \%$ \\
\hline Neottia nidus-avis & NT & - & $1-5 \%$ \\
\hline Ophrys insectifera* & NT & - & $<1 \%$ \\
\hline Pseudorchis albida & NT & - & $1-5 \%$ \\
\hline
\end{tabular}

* protected species

Cat (category): RE regionally extinct; CR critically endangered; EN endangered; VU vulnerable; NT near threatened

Crit (criterium): A severe population reduction B limited area in decline C small population in decline $D$ very small population/area

Eur pop: \% of European population

\section{Material and Methods}

The basis for the present paper is primarily the author's own work and nearly 45 years of experience of studying different aspects of the Nordic limestone landscape, including plant sociological studies, documentation and assessment of conservation values, floristic and phytogeographical studies, vegetation mapping, etc. which has resulted in numerous papers and conservation reports (some of which will be listed in the text). The most important contributions are conservation programs for basiphilous pine forests (one of the most orchid-rich of all habitats) in Norway and Sweden (see e.g. Bjørndalen 1985, 1986, 1987, 2006; Brandrud and Bjørndalen 1985; Bjørndalen and Brandrud 1989).

I have used different means to assess the extent to which the different species of orchids are protected. One important source has been the fact sheets provided by the Norwegian Environmental Agency for all of the protected areas in Norway ('the Nature Base'), available on http://www.miljodirektoratet.no. Information in the fact sheets on red listed species provided by Artsdatabanken, the Norwegian Biodiversity Information Centre. In addition, distribution maps from Artsdatabanken and occur- rences within conservation areas of some of the species included in this paper were examined.

Additional information can be found in a large number of conservation reports, which document areas of conservation interest, and also in many papers published in national botanical journals. However, it is difficult to combine this information with the actual distribution of the respective species and their representation in the network of nature reserves, or at least it is a time consuming task that is not yet complete. Thus, the present paper is a preliminary report, but I hope to work further with this material. The nomenclature for vascular plants follows Lid and Lid (2005).

\section{Vegetation (Nature) Types with Orchids}

Orchids can occur in a variety of types of vegetation and in different microhabitats within them. However, some of them are more important than others, and since the type of vegetation (or in a broader sense type of nature) is the most important criterion in most conservation contexts I will give a short presentation of the most important types. Most of them are rare and often have a high value as habitats for rare species and for high biodiversity in general. Classification of the types of nature 
in Norway (including also the especially valuable types) and more comprehensive information about them can be found in e.g. Fremstad (1997), Direktoratet for naturforvaltning (1999), Fremstad and Moen (2001), Halvorsen et al. $(2009,2015)$ and Lindgaard and Henriksen (2011). Most of the species of orchids in Norway occur in various types of forest, mostly rich communities in both conifer and deciduous forests. Many species (including also some of the forest species) occur in different types of open calcareous vegetation, e.g. rocky outcrops, dry meadows, screes and alpine heaths. Rich-fens and calcareous mires can be rich in orchids, and many of the rarest species are found in such habitats. Some species are favoured by scything both dry hay meadows and mires. Orchids also occur in sea shore habitats.

\section{Conifer Forests}

Orchids are mostly confined to calcareous or otherwise base-rich conifer forests. One of the most orchid-rich types of forest in Norway is basiphilous pine forest, i.e. light-open pine forests on very shallow calcareous soils (Bjørndalen 1985, 2006; Bjørndalen and Brandrud 1989). Such forests are rare, but occur scattered throughout the country north to Finnmark in $\mathrm{N}$ Norway. These basiphilous pine forests with their many microhabitats are generally rich in species of vascular plants, many of them rare. There is a great variation between different geographical regions, and e.g. species of dry meadows, steppes and rocky areas with a south eastern distribution are important in SE Norway, while calcicolous alpine species can be important in $\mathrm{N}$ Norway. There is also a great diversity of calcicolous fungi in this community. Orchids like Ophrys insectifera, Cypripedium calceolus and Cephalanthera rubra occur mainly in basiphilous pine forests and their associated communities. Many species also occur in ancient deciduous forests (e.g. Orchis mascula, Neottia nidus-avis and Cephalanthera longifolia), on calcareous rocks and screes (e.g. Epipactis atrorubens) and in dry to mesic base-rich meadows (e.g. Gymnadenia conopsea, Coeloglossum viride, Platanthera bifolia and P. montana). Many of the same species can also occur in rich spruce forests (low and tall types of herbaceous plants) on deeper brown earth. Of the other orchids in rich conifer forests the following should be mentioned: Dactylorhiza fuchsii, Listera ovata, Epipactis helleborine and Goodyera repens. Epipogium aphyllum requires conditions to remain stable over a long period of time and is confined to old-growth conifer forests, often richer stands on base-rich soil. Coniferous swamp forests can also contain orchids, richer types e.g. Listera ovata and poor types e.g. the non-calcicolous species Dactylorhiza maculata, Listera cordata and Corallorhiza trifida.

\section{Deciduous Forests}

The mixed thermophilous deciduous forests of Querco-Fagetea character in Norway are outposts of the Central European deciduous forest zone, but ancient decidu- ous forests occur along the coast and fjord districts north to Helgeland just south of the Arctic Circle, although Ulmus glabra occurs at Beiarn, which is even further north (Rønning 1954). The ancient deciduous forests can occupy extensive areas on south- and west-facing slopes in the western Norwegian fjord landscape. There is a high diversity of microhabitats in these forests, with many rare species. Orchids like Orchis mascula, Cephalanthera longifolia and Neottia nidus-avis have their core habitats in such forests, partly also e.g. Epipactis helleborine and Listera ovata. However, these species can even be found in rich conifer forests. Meadow species can occur in more open patches. In northern parts of Norway the thermophilous deciduous forests are replaced by birch forests or mixed deciduous forests with more boreal species such as e.g. Betula pubescens, Alnus incana, Populus tremula and Salix caprea/coaetanea. The rich boreal deciduous forests can also contain orchids such as e.g. Cypripedium calceolus, Neottia nidus-avis, Epipactis helleborine and Orchis mascula. Calcareous birch forests (mostly on screes) in $\mathrm{N}$ Norway are floristically and ecologically related to the basiphilous pine forests, and contain many of the same species (e.g. large populations of Cypripedium calceolus). Rich swamp forests with e.g. Alnus glutinosa and Salix spp. can occasionally contain rare orchids, and e.g. Epipactis palustris (and other rich-fen species) can occur in such forests.

\section{Open Calcareous Vegetation}

Many species of orchids occur in a variety of open communities on limestone, marble and dolomite. The open limestone vegetation in SE Norway consists mostly of rocky outcrops with a sparse cover of vegetation (Sedo-Scleranthetea communities) and more densely covered dry meadows on shallow soil (Trifolio-Geranietea communities), see e.g. Marker (1969) and Fremstad (1997). Dry meadows dominated by Geranium sanguineum can also occur on deeper sea shell deposits where some orchids can be found, e.g. Epipactis atrorubens and in rare cases even Ophrys insectifera. A special case is dry meadows with the rare Anacamptis morio on some small islands in the southernmost parts of Norway, but these habitats are not especially lime-rich (Andreassen and Åsen 1980; Baugen 2003). Open calcareous vegetation is a more important habitat of orchids in N Norway, and most of the Ophrys insectifera occurrences at Salten, Nordland, are on marble outcrops, in dry meadows on shallow soil, heaths, sea shell meadows, sand dunes and fine-textured screes with Dryas octopetala the dominant species (Bjørndalen 2006). Species such as e.g. Epipactis atrorubens, Coeloglossum viride and Gymnadenia conopsea can also be abundant in such vegetation. Orchids can also occur in alpine areas, most often in Dryas heaths, e.g. Chamorchis alpina, Coeloglossum viride, Pseudorchis straminea and Epipactis atrorubens. Lysiella oligantha is extremely rare, and occurs only at a few localities in the counties of Troms and Finnmark in N Norway. 


\section{Rich-fens and Calcareous Mires}

Many orchids are more or less confined to sloping mires and fens with calcium-rich ground water, habitats which are vulnerable to drainage and other disturbances. Many localities have been destroyed. Such mires were earlier mowed, and many of the rich-fen orchids are favoured by scything (see e.g. Moen 1990). Succession and/ or less intense grazing has affected some of these mires. The strong decline and local or regional extinction of many species of orchids is due to these negative effects, and some of the species are now endangered. Examples are Microstylis monophyllos, Nigritella nigra, Epipactis palustris, Dactylorhiza traunsteineri and Herminium monorchis. Dactylorhiza incarnata (including both ssp. incarnata and ssp. cruenta), D. lapponica and Hammarbya paludosa occur more widespread.

\section{Hay Meadows and Culturally Influenced Sites}

Many species of orchids occur in mowed, often dry base-rich meadows and are favoured by scything. The most prominent example is Dactylorhiza sambucina, which has its core area in hay meadows in the interior of Telemark (Nordal and Wischmann 1996; Norderhaug et al. 1997). Pseudorchis albida is another rare species that prefers mowed or grazed habitats. Many other species of orchids can occur in dry and mesic hay meadows, e.g. Platanthera bifolia, P. montana, Gymnadenia conopsea, Coeloglossum viride and Listera ovata. Rich hay meadows are rapidly disappearing because they are not mowed any longer or affected by the application of fertilizer, and proper management is necessary to preserve the occurrences of e.g. Dactylorhiza sambucina (see below).

\section{Sea Shore Meadows, Salt Marshes and Other Sea Shore Habitats}

Only a few of the Norwegian orchids are confined to sea shores. In particular the rare and endangered Dactylorhiza purpurella and the disputed species D. praetermissa (see e.g. Skrede 2001 and below). Some species can occur in sand dunes with calcareous material, e.g. Epipactis atrorubens and the red listed taxa Coeloglossum viride ssp. islandicum and Epipactis helleborine ssp. neerlandica.

\section{Threats and Their Effects on Orchids and Orchid Habitats}

Rare orchids are vulnerable to wide range of disturbances, ranging from drainage, succession and clear-cutting of forests, etc to complete destruction of large parts of the landscape, which have negative effects on their viability and lead to a reduction in population size. Areas in the interior Oslofjord and the limestone areas from the Cambro-Silurian period in SE Norway are densely populated and have for a long time been affected by urban development, infrastructure and industry, and much of the original natural and agricultural landscape has disappeared. These lowland areas are a climatically favourable region with the highest total biodiversity in Norway. The intensity of building was especially high after the Second World War, and e.g. half of the valuable basiphilous pine forests in the Cambro-Silurian district Skien-Langesund was destroyed between 1972 and 1986 (Bjørndalen 1988). Many orchid localities, especially those of rare xerothermic species confined to open calcareous rocks and meadows in the SE Norwegian lowlands were destroyed. In addition, the building of holiday cabins along the Oslofjord and the Skagerak coast also destroyed many valuable areas, and e.g. affected the basiphilous pine forests and localities where rare species such as e.g. Ophrys insectifera occurred (Bjørndalen and Brandrud 1989). Even small-scale house building in remote areas adversely affected the localities of e.g. O. insectifera in its core area in N Norway (Bjørndalen 2006). Limestone quarrying completely changes the landscape and basiphilous pine forests are particularly susceptible to such activities, which also destroyed areas with rich orchid floras (Bjørndalen and Brandrud 1989). However, there are also examples of abandoned quarries being secondary habitats for rare orchids such as Ophrys insectifera and Cephalanthera rubra (Økland 1984; Hanssen 2006). Some of the few remaining localities for Herminium monorchis in Østfold, which were protected, were affected and partly destroyed by the building of boat depots on land and the transformation of sea shore meadows for recreational use (cf. fact sheet 156 from Artsdatabanken).

The paradox is that more subtle disturbances have been more harmful to orchids (and many other rare species) than the disturbances described above. In particular, drainage, cultivation and afforestation of mires and wetlands, but also succession in such habitats due to changes in agricultural practices that resulted in less intense grazing, cessation of mowing (including mires) and an increase in the application of fertilizer. Nigritella nigra, Epipactis palustris, Microstylis monophyllos and Herminium monorchis are examples of rich-fen species that were seriously affected. Those species that prefer base-rich hay meadows and other sites in the cultural landscape are adversely affected when these habitats are no longer mowed or are over fertilized. Examples are Dactylorhiza sambucina and Pseudorchis albida. Many other species are also negatively affected by succession and growths of dense thickets in rich conifer and deciduous forests (see examples below). Intensive use of recreation areas can affect some localities with orchids, e.g. Ophrys insectifera (Bjørndalen 2006). Flower picking and digging orchids up to plant in gardens is a problem as was in earlier days the collection of herbarium specimens by botanists (an activity which contributed to the extinction of Liparis loeselii).

\section{Protection of Norwegian Orchids and Their Habitats}

Strict protection based on environmental laws is essential for safeguarding biological occurrences, both for the organisms themselves and their habitats. Conservation work in Norway became more systematic after 1970 with the passing of the Law of Nature Conservation and 
the establishment of the Ministry of the Environment. A large number of nature reserves and other conservation areas were established (around 2900 at the moment), reflecting a representative selection of the great variety of types of nature in Norway. The new Law of Nature Diversity passed in 2009 (http://lovdata.no/dokument/NL /lov/2009-06-19-1) is an even better tool for nature conservation. National parks and some reserves and landscape protection areas can include extensive parts of undisturbed or little disturbed nature.

The official responsibility for nature conservation in Norway has three levels. The Ministry of Climate and Environment and their scientific unit Norwegian Agency of Environment, which is located in Trondheim have the national and international responsibilities, and the establishment of all conservation areas are approved by the King and his council (the Government). The regional level consists of the Section for Environment as a division under the County Governor in each of the 18 counties (Oslo and Akershus have a joint County Governor). These units have the daily responsibility for their counties and have a good competence in environmental sciences. Finally, the 428 local municipalities have responsibility for safeguarding valuable types of nature and red listed species by planning and carefully controlling activities that might adversely affect such occurrences. However, the local level of nature conservation does not function optimally and political signals that the responsibility of municipalities for nature conservation are to be increased could present problems (see discussion below).

Orchids were early recognized as conservation objects and some botanists worked hard to get some special occurrences protected. For instance, the small Cypripedium calceolus locality Versvik mentioned below was protected in 1928. The large plant protection area Junkerdalen-Balvatn in N Norway with one of the largest populations of C. calceolus and numerous rare alpine species was established in 1935 (recently transferred to a national park and a large nature reserve).

The most important contributions to nature conservation in Norway are the thematic conservation programs for selected types of nature, namely mires, wetlands, conifer forests, ancient deciduous forests and other rich deciduous forests and coastal environments. Most of the network of nature reserves is associated with these types of nature. This was extremely beneficial for orchid conservation since most of the species occur in these types of nature. Good examples are forest species such as e.g. Cypripedium calceolus, Ophrys insectifera, Cephalanthera rubra, C. longifolia, Epipogium aphyllum and Neottia nidus-avis and rich-fen species such as e.g. Nigritella nigra, Epipactis palustris, Dactylorhiza traunsteineri and Microstylis monophyllos.

\section{Protection Status of Selected Orchid Species}

General information about distribution is taken from Lid and Lid (2005), but other references are included if the respective species is treated in more detail in papers, reports or in the series 'Maps of distribution of Norwegian vascular plant' (Fægri 1960; Gjærevoll 1990; Fægri and Danielsen 1996; Elven et al. 2013). The on-line distribution maps provided by the Norwegian Biodiversity Information Centre (Artsdatabanken) were also consulted (http://www.artsdatabanken.no) for some of the species.

\section{Anacamptis morio}

A. morio has one of the most limited distribution of all Norwegian orchids and occurs only on some small islands in the two municipalities Grimstad and Lillesand in Aust-Agder in the southernmost parts of Norway (Fægri 1960; Andreassen and Åsen 1980; Pedersen and Åsen 1994; Baugen 2003). This species occurs in grassrich meadows and on rocks near the sea. The status of A. morio (up to 2012) is treated in http://botanikk.no /Narrmarihand/htm. A slight decline was recorded during the last decade, and this species is susceptible to ongoing succession on small islands. As a paradox, sheep grazing which was supposed to open up the island landscape seems to have negative effects as many plants are eaten by the sheep. No protection areas for this species have been established so far. A. morio has the red list status near threatened and it is questioned whether the status should be adjusted to endangered.

\section{Cephalanthera longifolia}

C. longifolia has mainly a coastal distribution in Norway and occurs north to the Trondheimsfiord area (Fægri 1960; Nordal and Wischmann 1986). This species is mostly found in rich deciduous forests, but can occasionally be important even in basiphilous pine forests (Nordfjord in Sogn og Fjordane, cf. Bjørndalen 2005). Viable populations occur in many of the nature reserves with ancient deciduous forests (especially in W Norway), but the representativeness of the overall protection has not been evaluated. The most important inland occurrence (Kleppefjell in Hjartdal, Telemark, cf. Nordal and Wischmann 1986) is situated in a basiphilous pine forest reserve. It is supposed that $C$. longifolia can endure succession better than many other species of orchids since it is often found in dense stands in deciduous forests.

\section{Cephalanthera rubra}

C. rubra is one of the most vulnerable of the forest orchids, and an action plan for this species has been presented (Direktoratet for naturforvaltning 2006). This species has a strict south eastern distribution and is mostly confined to a few localities east of Oslofjord (Fægri and Danielsen 1996; Hanssen 1996). This species is primarily found in basiphilous pine forests and associated communities (Bjørndalen and Brandrud 1989; Hanssen 1996), and destruction of such forests for building houses has been extensive in some of the Cambro-Silurian areas in the Oslo region, e.g. Eiker (Hanssen 1996) and 
Skien-Langesund (Bjørndalen 1988). C. rubra is also susceptible to clear-cutting and succession and even flower picking has been documented (Direktoratet for naturforvaltning 2006). This species is recorded in nine nature reserves (mostly basiphilous pine forests), but some other localities are not protected other than in terms of the general protection of this species (Direktoratet for naturforvaltning 2006). Management is practised in some areas, especially the thinning of thickets in forests. Hanssen (2006) and Hoell (2013) give status reports on this work along with the action plan for this species.

\section{Cypripedium calceolus}

Most of the occurrences of C. calceolus in Norway are associated with basiphilous pine forests (Fig. 1), but it also occurs in calcareous birch forests on screes in N Norway (Bjørndalen and Brandrud 1989). It can also be found in calcareous spruce forests on shallow marble soil at Hattfjelldal in county Nordland (Bjørndalen 2003) and in other rich spruce and deciduous forests on deep brown earth. In rare cases this species can be found in alpine areas on calcareous screes (e.g. in Bøverdalen in the Jotunheimen area). C. calceolus and Ophrys insectifera are important icons ("charismatic" species according to Bjørndalen 2006) in the conservation plans for basiphilous pine forests (Bjørndalen and Brandrud 1989). The most important threat is clear-cutting, but also general succession resulting in thickets developing in e.g. basiphilous pine forests, which can reduce the viability of this species. Flower picking and digging up plants with roots for planting in gardens are also implicated. The implementation of the conservation plans for conifer forests and rich deciduous forests has resulted in numerous nature reserves where $C$. calceolus is abundant. These reserves are situated within the distribution of this species, which is mainly in the east (Elven et al. 2013), i.e. from Porsgrunn in Telemark in SE Norway and north to Alta in Finnmark. The largest populations are in N Norway and there are perhaps several thousand clones at each of the localities at Junkerdalsura in Nordland and Brennfjell in Troms (see e.g. Elvebakk and Sortland 1985). However, even if the representation of C. calceolus in protected areas can be considered as good there are still localities that need to be protected. Most of the occurrences do not need any special management, but the problem of succession resulting in dense shrubberies in basiphilous and deciduous forests can be a problem in certain areas. A good example is the tiny plant protection area established in 1928 at Versvik in Telemark, SE Norway. The locality was fenced and as a consequence a dense shrub layer developed. In 1972 there was only one small group of C. calceolus (Bjørndalen 1972), but after the area was made a nature reserve the shrubbery was thinned in the 1980s and C. calceolus responded quickly and already in 1996 (personal observations) new clones had spread throughout the reserve from the original group.

\section{Dactylorhiza praetermissa}

D. praetermissa is known only from one locality (Stad in Sogn og Fjordane, W Norway), where it occurs in brackish sea shore meadows together with $D$. purpurella. Its existence in Norway was controversal and disputed (Nordhagen 1972; Wischmann 1989; Skrede 2001), and the locality was supposedly destroyed by the lowering of the water table for cultivation purposes (Skogen and Odland 1991). However, later on new plants were re-established (Skrede 2001) and this occurrence is cited in the latest edition of the Norwegian flora (Lid and Lid 2005). As a consequence, $D$. praetermissa should be protected. Skrede (2001) mentions the need for management. This species has been given the red list category critically endangered in the fact sheet from Artsdatabanken, but has not been included in the current red list (Kålås et al. 2010).

\section{Dactylorhiza purpurella}

D. purpurella and D. praetermissa are the only species of orchids that exclusively occur in sea shore meadows and salt marshes, $D$. purpurella also occurs in depressions in sand dunes. $D$. purpurella occurs at a few localities on the outer parts of the western Norwegian coast between Jæren in Rogaland and Ørlandet in Sør-Trøndelag (Lid and Lid 2005), and has the status endangered in the red list (Kålås et al. 2010). This species occurs in some nature reserves, e.g. in Hå, Rogaland and Giske, Møre og Romsdal. It is now only known to be present at $4-5$ of the almost 20 previously recorded localities according to the fact sheet from Artsdatabanken and the decline seems to be primarily due to succession. It is not known whether all the localities where it is currently recorded are protected (distribution map not available on-line).

\section{Dactylorhiza sambucina}

D. sambucina has a strictly limited distribution in Norway occurring in interior parts of Telemark and adjacent areas (Nordal and Wischmann 1987; Fægri and Danielsen 1996). This species, of which only the yellow form occurs in Norway, seems to be favoured by mowing and is mostly found in base-rich hay meadows and more rarely in pastures (Norderhaug et al. 1997; Bratli and Myhre 1999). A more natural occurrence is recorded in an area of basiphilous pine forest with patches of open calcareous vegetation at Kleppefjell in Hjartdal (Nordal and Wichsmann 1987), which is now a nature reserve. D. sambucina is not recorded in other conservation areas, which poses a challenge for the conservation of this species since it is dependent on long term management. However, local farmers and organizations are aware of this species (which is also designated as the official county flower of Telemark) and voluntarily manage the localities by scything. Such activities should be agreed with the County Environmental Section. 


\section{Epipactis palustris}

E. palustris is restricted to some localities around Oslofjord with some isolated occurrences at Jæren and Karmøy in Rogaland (Fægri and Danielsen 1996; Hanssen 1998). This species is confined to rich-fens, rich swamp forests and other wetlands, and is vulnerable to habitat destruction, drainage and changes in hydrological regimes, cultivation, water and soil pollution and successional development of reed beds in wetlands. It has disappeared from more than half of the earlier known 42 localities and an action plan is now in place (Hanssen 2011; Hoell 2011a). The red list status is endangered (fact sheet 157 from Artsdatabanken), but E. palustris occurs at nine of the remaining localities within nature reserves and landscape protection areas (Hanssen 2011). There are relatively large populations at Ultvedttjern in Ringerike, Buskerud (Bjørndalen 1999), and viable populations in other conservation areas. A voluntary agreement with the farmer who owns the ground where E. palustris occurs at Karmøy, Rogaland, about fencing out grazing animals has so far been successful (Lundberg 2013). An interesting experiment in which the remaining plants in the nature reserve Oppsiømyrene in Akershus were transferred to the Botanical Garden in Oslo for later reintroduction was recently carried out, opens up the possibility of managing endangered species with small populations in this way (Røsok et al. 2013).

\section{Epipogium aphyllum}

The Ghost Orchid (E. aphyllum) is a fascinating saprophytic species, which can remain dormant for several years. It has a marked eastern distribution in Norway and occurs scattered north to Porsanger in Finnmark (Wischmann 1965; Elven et al. 2013). It is one of the few vascular plants confined to old-growth conifer forests, a type of nature otherwise characterized by a high diversity of fungi, lichens, mosses and wood-living insects (especially beetles) associated with rotting trees and dependent on it remaining undisturbed for a long time. These organisms are susceptible to clear-cutting and modern forestry is a threat to almost $50 \%$ of the species on the Norwegian red list (Kålås et al. 2010). E. aphyllum prefers moss-rich patches in rich spruce and pine forests, but occasionally occurs in old-growth birch forests and other boreal deciduous forests. The conservation plans for conifer forests has over the last two to three decades been implemented to a high degree and this species occurs in nature reserves throughout its distribution. However, there is no proper evaluation of how representative the occurrences in protected areas are compared with the known localities of the species (see discussion below). There are also still some old-growth conifer forests left to be protected.

\section{Herminium monorchis}

H. monorchis has suffered a dramatic reduction in its distribution from earlier occurring scattered through- out SE Norway to occurring currently only in the outer Oslofjord (Fægri and Danielsen 1996; Lid and Lid 2005), and its status on the red list is critically endangered (Kålås et al. 2010). The decline of $H$. monorchis started early, and only seven localities were known after 1955. This species is confined to rich-fens and calcareous wet meadows, types of habitat that are strongly susceptible to drainage and other types of destruction. The three remaining populations, with an estimated 500 individuals, occur at Asmaløy in Hvaler, Østfold (according to fact sheet 156 from Artsdatabanken), both inside the coastal and marine national park Ytre Hvaler and in a nearby nature reserve. The habitat of this species in the national park is currently being managed. An action plan for this species is being prepared according to a web note from the Ministry of Environment in 2011, but it has not been possible to verify this.

\section{Lysiella oligantha}

L. oligantha (former names Platanthera oligantha; P. obtusata ssp. oligantha) is one of the rarest orchids in Norway. It has an extremely restricted distribution in Europe, where the only European populations are in the counties Troms and Finnmark in northernmost Norway and Abisko National Park in N Sweden (Gjærevoll 1990; Høiland 1990; Alm 2012). The nearest occurrences are in the Jenisei area in eastern Siberia from where it spreads further east to Kamchatka (Hultén and Fries 1986). This species was earlier over-collected by botanists (Alm 2012) and suffered from habitat destruction even after it was protected. A sad example was road construction work in 2011-12 at Kåfjord in Alta, Finnmark, which destroyed a classic locality of $L$. oligantha (Alm 2012, 2013). Norway together with Sweden has a special international responsibility to protect this species. The largest viable populations in Norway are found in the Reisa National Park. This species occurs also in the conifer forest reserve Skoganvarre at Porsanger. An earlier record from Skibottsdalen in Troms (Benum 1958) has not been confirmed in recent years (Høiland 1990), but this occurrence is probably situated within the nature reserve Brennfjell. At least, there are viable populations on the mountain Sáhkkobátni at Kåfjord (Alm 2012), an area which is not yet protected.

\section{Microstylis monophyllos}

The rich-fen species M. monophyllos (former name Malaxis monophylla) has undergone a similar reduction in distribution to Herminium monorchis, as it earlier occurred scattered throughout SE Norway (Schumacher et al. 1992; Fægri and Danielsen 1996; Lid and Lid 2005). Most of its former localities were destroyed by ditching and drainage of mires and wetlands. Some of the few remaining localities occur within nature reserves such as e.g. the "classic" locality Karusputten and the adjacent Holbekken at Nordmarka in Oslo (see e.g. Moen and 
Wischmann 1972; Schumacher et al. 1982). M. monophyllos is included in a surveillance program for selected species in the county of Oslo, and the total number of individuals in the years 2010-14 varied between 71 and 113 (http://www.naturarv.no). The species occurs also in the nature reserves Arekilen at Hvaler, Østfold, and Gullerudtjern at Ringerike, Buskerud.

\section{Nigritella nigra}

N. nigra is confined to hay meadows and traditionally mowed mires, and is now extremely rare in both Norway and Sweden. The taxonomy of the Nigritella complex is uncertain, but the Scandinavian population seems to be the endemic ssp. nigra (Hedrén 1999; Hedrén et al. 2000) although the plants on serpentine are given the name Gymnigritella runei, which is regarded as an endemic (Teppner and Klein 1989). The current Norwegian flora (Lid and Lid 2005) accepts only Nigritella nigra whereas the Nordic flora (Mossberg and Stenberg 2003) lists both taxa as Gymnadenia nigra and G. runei, respectively. Anyway, the restricted distribution of this complex in the interior parts of Sør-Trøndelag and adjacent areas in Norway and Jämtland and Härjedalen in Sweden has decreased markedly and this species is given endangered status in both the Norwegian and Swedish red lists (Gärdenfors 2005; Kålås et al. 2010). In addition, there are some isolated occurrences at Troms in northernmost Norway (Johansen 1981; Engelskjøn and Skifte 1984; Sætra 1987). The number of occurrences recorded in Norway is 44 , and an action plan for N. nigra in Norway has recently been presented (Miljødirektoratet 2013). This report gives a good summary of the biology and ecology of this species, with a comprehensive reference list including international literature. The three decade long investigation at the mire reserve Sølendet at Røros, Sør-Trøndelag has given a wealth of information on N. nigra and other plants favoured by the scything of mires and on mire ecology in

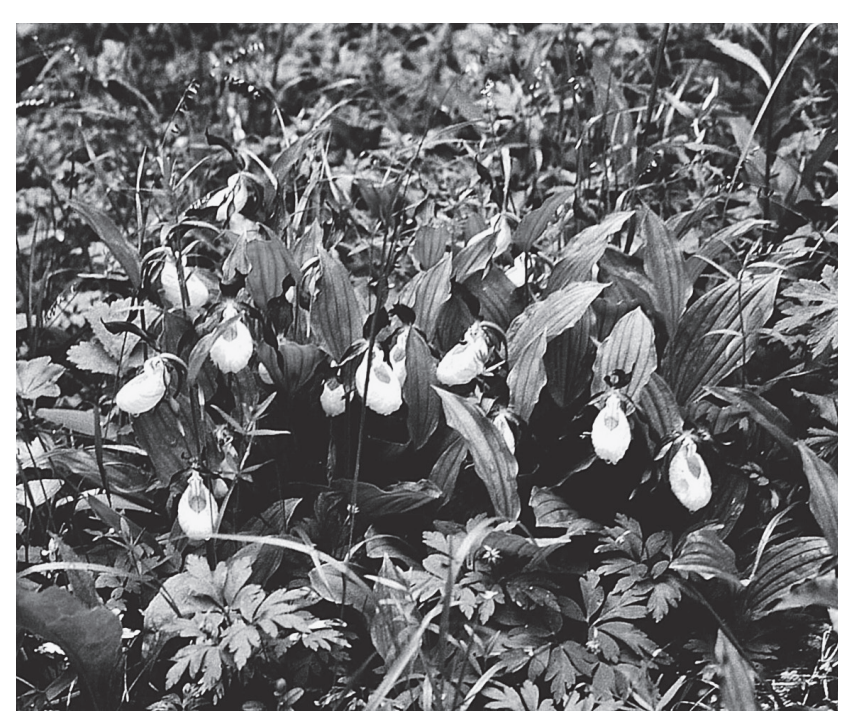

Fig. 1 Cypripedium calceolus occurs abundantly in the basiphilous pine forests in the nature reserve Bergsåsen in Snåsa, Nord-Trøndelag. general (Moen 1990; Moen and Øien 2003, 2009, 2012; Øien and Moen 2001, 2005, 2009). Primary localities for $N$. nigra are probably naturally open areas rich in herbaceous plants along rivers, creeks and at the edge of mires and of water filled depressions in sloping mires, habitats that are grazed by small rodents such as lemmings (Moen and Øien 2012). The most serious threats to this species are succession and the application of fertilizers. The thorough studies of $N$. nigra at Sølendet have provided important information for management of this species and of mires and rich-fens in general. Thinning of trees and shrubs and mowing using scything machines are used to restore mires, and more or less regular mowing is recommended as a management procedure for the reserve (Miljødirektoratet 2013). Similar management of the N. nigra localities in Sweden was successful (Björkbäck and Lundquist 2005). There are also viable populations of N. nigra at Kvikne, Hedmark, within and in contact with the Knutshø landscape protection area where it occurs in more primary habitats subject to less cultural influence (Hoell et al. 2011), and a status report for implementation of the national action plan for this species has been presented for the occurrences in the counties of Hedmark and Oppland (Hoell 2011b). N. nigra was given the status of priority species by the Ministry of Climate and Environment in May 2015, which brings this species under the protection of the Law of Nature Diversity. Only 13 species have been given this status so far.

\section{Ophrys insectifera}

Bjørndalen (2006) discusses the conservation status of $O$. insectifera in Norway and presents an overview of the localities where it is protected. Most of the Norwegian occurrences are in basiphilous pine forests, and O. insectifera together with Cypripedium calceolus are explicitly used as "iconic" species for promoting the conservation of this type of vegetation (Bjørndalen and Brandrud 1989). This species is especially vulnerable to habitat destruction caused by building of houses and holiday cabins, but clear-cutting and mechanical damage caused by logging machines, growth of shrubs in basiphilous pine forests and intensive use of recreation areas also adversely affect this species (Bjørndalen 2006). O. insectifera has three distinct distribution centres in Norway (Elven et al. 2013). The SE Norwegian sub region is the most extensive, and almost all localities were protected in 2005 (Bjørndalen 2006). Some additional reserves were established since then. The same is the case for the sub region north of Trondheimsfjord in C Norway, were large populations occur in the outstanding botanical locality and nature reserve Bergsåsen at Snåsa, Nord-Trøndelag. The third sub region occurs just north of the Arctic Circle in the Salten district in Nordland, where locally large populations occur in both basiphilous pine forests and in particular in open calcareous vegetation such as dry meadows, rocky outcrops, sea shell meadows and screes. Most of the localities where O. insectifera occurs in ba- 
siphilous pine forests are protected as nature reserves and a few of the occurrences in open calcareous vegetation were protected in 2005 (Bjørndalen 2006). However, many of the valuable localities with such vegetation were recently made nature reserves. A notable exception is Ausvika north of Bodø where the large population in sea shell meadows in a municipal recreation area is being adversely affected (see discussion below).

\section{Other Species}

Characteristic species of ancient deciduous forests and other rich deciduous forests such as e.g. Orchis mascula, Neottia nidus-avis and Epipactis helleborine seem to be well represented in nature reserves. These species, in addition to Dactylorhiza fuchsii, Goodyera repens and the more mesic Listera ovata do also occur in many reserves with basiphilous pine forests and rich spruce forests. Rich-fen species such as e.g. Dactylorhiza traunsteineri, D. incarnata (both subspecies incarnata and cruenta), D. lapponica and Hammarbya paludosa are found in many mire reserves. Epipactis atrorubens occurs in a variety of dry calcareous communities (included basiphilous pine forests) and occurs in reserves throughout its distribution area from south to north. Widespread meadow and rich forest species such as e.g. Gymnadenia conopsea, Platanthera bifolia, P. montana and Coeloglossum viride obviously occur in a variety of reserves, but there are no studies on whether they are abundant there. The same is the case for species with a more alpine affinity such as Pseudorchis albida, P. straminea and Chamorchis alpina. $P$. albida is red listed and considered as threatened in the cultural landscape, but seems to be more common in primary habitats in certain areas such as e.g. mountain areas at Sunnmøre, W Norway (Holtan and Grimstad 2001). Widespread and non-calcicolous species such as Corallorhiza trifida, Listera cordata and Dactylorhiza maculata are well represented throughout the country in reserves with moist forests, wet meadows and poor to intermediate bogs and mires.

\section{Discussion and Concluding Remarks}

Conservation and management practices are complicated matters and should be based on good science and good collaboration between the environmental authorities and scientists. Protection in the form of a nature reserve (or other protection area categories) enshrined in the Law of Nature Diversity as well as IUCN standards, both for organisms and ecosystems (see e.g. IUCN 2008; general discussion in Kålås et al. 2010; Rodriguez et al. 2011), is the best way to sustain current levels of biodiversity and protect valuable habitats. Strict regulations for a reserve and its proper management can then be implemented. Landscape protection areas and national parks can also protect rare species, although these conservation categories are generally weaker than nature reserves.
A good network of nature reserves with rare orchids and orchids in general has been achieved since most of the valuable habitats with orchids are important conservation areas, such as e.g. rich conifer forests, rich ancient and boreal deciduous forests and rich-fens. Action plans for some orchid species are being implemented. I will discuss some aspects of orchid conservation such as whether there is a good representation of orchids in the network of protected areas and the need for further conservation and management and the challenges and limitation that lay ahead before we can claim that the protection of Norwegian orchids and their habitats is adequate.

\section{Assessment of the Representation in Terms of Species of Orchids in the Network of Protected Areas}

Artsdatabanken (the Norwegian Biodiversity Information Centre) has published standardized fact sheets for many of the red listed species, including the orchid species presented in the present paper (http://www .artsdatabanken.no/publikasjoner/faktaark). These fact sheets are also part of my background material for assessing the representation of orchids in protected areas. However, the quality of the descriptions in the fact sheets is variable, but they are currently being updated and the presentation for some of the species improved.

The relationship between threats, registration of their status in the field and the conservation and management needs of some species, i.e. the species for which there are special action plans, such as Epipactis palustris (Hanssen 2011), Cephalanthera rubra (Direktoratet for naturforvaltning 2006; Hanssen 2006) and Nigritella nigra (Miljødirektoratet 2013) are being given more attention. The Norwegian Botanical Society is also involved in the implementation of various aspects of the actions plans (see Hoell 2011a, 2011b, 2013). Some species are dealt with in more detail in terms of the list of localities, field status and recommendations for further protection. Here I can mention e.g. Lysiella oligantha (Høiland 1990) and Ophrys insectifera (Bjørndalen 2006). L. oligantha needs special attention, because even though there are viable populations in the Reisa National Park (and 1-2 nature reserves) the situation is nevertheless alarming as several localities have recently been destroyed (Alm 2012). Dactylorhiza purpurella is another species that urgently needs an action plan. The only locality with $D$. praetermissa at Ervik in Stad should be protected and managed properly. This species should also be included in the next edition of the Norwegian red list. The status of Anacamptis morio on small islands at Aust-Agder is alarming because of the threat both from succession and from grazing by sheep currently being used to stop succession occurring (!), and its red list status should be changed to endangered. Herminium monorchis with only three localities needs special attention and steps need to be taken to improve the habitat for this species in the Ytre Hvaler National Park. There are very few localities for Microstylis monophyllos, but they are protected within some mire reserves. 
However, a more detailed assessment of the protection is needed. Dactylorhiza sambucina with its preference for hay meadows is dependent on management and the continuation of mowing (Norderhaug et al. 1997), and formal agreements between the environmental authorities and local farmers and organizations should be agreed.

Finally, a more detailed assessment of the conservation status of the more widespread red listed species, such as Cypripedium calceolus, Epipogium aphyllum, Pseudorchis albida, Neottia nidus-avis and Dactylorhiza traunsteineri, and protection of their localities is desirable. Such an assessment is time-consuming and requires the study of distribution maps, herbarium data, published and unpublished papers and reports as well as checking the Nature Base. I have carried out a quick check for Epipogium aphyllum and Cypripedium calceolus using the distribution maps provided by Artsdatabanken, by enlarging the dots to determine the exact positions and whether they are situated inside protection areas. There are important occurrences of these two species in nature reserves and other conservation areas, but it is difficult to judge whether they are representative. Only around 20 of the 221 dots for E. aphyllum (around half of them, those with coordinated positions, were checked) are currently inside nature reserves and national parks. A high number of dots (almost 1100) were for C. calceolus. The majority of them were not coordinate based and only attributed to a municipality as a whole, and therefore impossible to use. However, C. calceolus is protected in more than 30 conservation areas, and most of them include important types of habitats for species such as e.g. basiphilous pine forests and other rich conifer forests and in N Norway also rich deciduous forests. To conclude, these distribution maps must be used with caution and are not suitable on their own for making a proper assessment. There is no information on whether this species still occurs at a particular locality or if it is based on old and dubious collections or records. Another problem with E. aphyllum is that this species can be dormant for many years at a locality and it is therefore difficult to confirm its presence. But like C. calceolus, many of the important localities for E. aphyllum are included in the national conifer forest conservation program. I want to carry out a more detailed analysis of the distribution of C. calceolus.

\section{The Need for Management}

Management connected with the protection of orchids and their habitats are repeatedly mentioned throughout this paper, and it is obvious that many species are dependent on some kind of management (e.g. Dactylorhiza sambucina, Nigritella nigra, Epipactis palustris and Herminium monorchis). Management of many of the nature reserves with red listed orchids is needed. The reasons for such management are manifold and complex, and thorough research is often necessary to develop a proper management regime. In other cases just the thinning of thickets can improve a locality for some species. There are also more fundamental questions regarding management and restoration, e.g. ex situ rescue as in the case of Epipactis palustris (Røsok et al. 2013).

The network of nature reserves has increased steadily over the last few decades, but following up with management plans and proper funding has generally not been given the highest priority. The most common problem is succession in both forested and open parts of the reserves, and the negative effects of e.g. the earlier draining of mires and wetlands still affects the quality of these sites. In the most serious cases (like E. palustris) the loss of a rare species one wants to protect can result. The Governmental Revision Agency has focused on this problem, and has criticized the environmental authorities for not giving priority and funding the management of the reserves (Riksrevisjonen 2006).

The complexity of the management of orchids indicates that it needs to be based on good and detailed scientific research (as e.g. in cf. Moen 1990; Moen and Øien 2003, 2009) on for e.g. their population ecology, pollination, mycorrhizal relationships, demography and effects of land use. Also comparisons with management and its implementation in other European countries (e.g. Fennoscandia, N Europe, The British Isles) can be informative.

\section{Habitat Protection vs. Species Protection}

The Law of Nature Diversity makes it possible to protect species and 13 red listed species of orchids are protected in Norway. This protection is meant to secure the localities of these species against flower picking, activities that negatively affect these species and the destruction of their habitats and provide a signal to local authorities, developers and the public that these localities are in need of special care. But is the formal protection of law enough to secure the populations of these rare species without following up with special initiatives? And if the latter are necessary who is responsible for carrying them out?

A good example of this problem are the rich occurrences of Ophrys insectifera at Ausvika north of Bodø, Nordland. There are several large populations of this species at Ausvika (own material) and in good flowering years there can be several hundred individuals. The vegetation is a mixture of sea shell meadows and marble outcrops with shallow soil dominated by Dryas octopetala, partly also calcareous sand dunes and birch thickets with tall herbaceous plants. The calcareous meadows are extremely species-rich and contain rare alpine species such as e.g. Kobresia myusuroides and Oxytropis lapponi$c a$, and I have recorded there almost 70 species of vascular plants and mosses (many calciphilous) in $1 \mathrm{~m}^{2}$ plots. Ausvika is also a popular recreation area and designated as an official area for recreational use by the municipality of Bodø. The resulting intensive use, trampling and erosion in many places has had a strong negative effect on the vegetation. There are also marked signs of illegal off-road driving. In addition, the development of birch 
thickets has had an adverse effect on the rich open calcareous vegetation, and thinning and management is needed. There is also a need to revegetate the eroded areas. The municipality is only concerned with the recreational aspects, not the safeguarding of $O$. insectifera. It should at least have provided information to the public about the vulnerable nature of the area and how it should be treated. The protection of $O$. insectifera under the present conditions at this locality has little value.

The Ausvika example is not unique, and many of the non-protected areas where red listed species occur are potentially likely to be destroyed. Protection of the entire habitat is crucial for safeguarding these species so only a vague species protection without any specific actions makes the future of many of these populations of rare species quite uncertain. More subtle effects associated with succession and forestry practices are also part of the problem and need to be addressed if proper management is to be adopted.

\section{Local vs. Governmental Conservation}

If the locality at Ausvika had been designated a nature reserve or landscape protection area the environmental authorities could have carried out proper management, given clearer rules and restrictions for the use of certain parts of the area and provided better control. The county environmental authorities are generally competent and have the necessary legal tools to safeguard biodiversity. They have the daily responsibility for the conservation areas in their respective counties and are the keepers of an outstanding network of nature reserves, which includes examples of the entire range of different types of nature with high species diversities present in Norway. At the national level the Norwegian Environmental Agency provides the scientific basis for the quality of the security at all conservation areas and is a guarantor that Norway will adhere to international conventions and agreements.

The 428 local municipalities protect nature in different ways. They are responsible for taking care of valuable nature and species within their borders, which are not protected by the Law of Nature Diversity, and for integrating this into their planning and other activities. All of the municipalities are responsible for elaborating plans for registering biodiversity. Direktoratet for naturforvaltning (1999) has specified 56 types of nature and numerous subtypes, which are of special value for biodiversity and red listed species, and provided guidelines on how this work should be carried out. Over the last 20 years all over Norway there have been projects on nature conservation and incentives for municipalities to employ environmental advisors. However, as a result of the decline in municipal economies these advisors were quickly dispensed with when governmental incentives ceased.

Political signals and priorities influence all parts of society and can have serious consequences for nature conservation both at national and regional/local levels. Although it is not easy to document in a scientific pa- per it is highly relevant to safeguarding rare species. The present conservative government in Norway shows signs of changing from favouring governmental control of the protection of nature to giving municipalities increased freedom to manage their natural resources. This is a part of the process to weaken the regional environmental authorities by reducing their control over the municipalities and ability to object to a municipality authorizing the building, e.g., of marinas, apartments, office complexes, etc. in the littoral zone, which they are currently allowed to do.

As mentioned above, the municipalities have little competence in biological sciences and there are often local pressure groups and developers with economic resources that influence and lobby the municipal administration and politicians. Volunteers working in local organisations interested in, e.g., botany, ornithology, entomology and nature conservation, everyday face problems, which local authorities are asked to adjudicate on, however, these local organisations often feel they lose out to strong economic interests. A problem is that e.g. private entrepreneurs and even municipal workers do not know where the valuable habitats and rare species occur, and there are many reports of destruction of nature due to lack of information. Even if valuable areas are safeguarded and regulated as nature areas a new municipal board after an election can signal other priorities for future planning. The conclusion is that protection based on government legislation and maintaining the competence and power of the environmental sections of the county councils to guide and correct the municipalities is the best way to sustain biodiversity.

This discussion is relevant also for orchid protection in various ways. The biodiversity plans of the municipalities are supposed to locate sites with valuable types of nature and red listed species on maps, which are coordinated with other thematical maps and actively used in the planning process and different activities. Since many of the localities of the generally protected and red listed species of orchid are outside nature reserves the municipalities are responsible for safeguarding them. Also many of the valuable types of nature with high biodiversity as defined by the Direktoratet for naturforvaltning (1999) are rich in orchids, e.g. basiphilous pine forests, ancient deciduous forests, open calcareous vegetation, rich-fens and dry hay meadows. The latter habitat needs management like scything, and such procedures are a challenge for a local municipality to fund, administrate and implement.

\section{REFERENCES}

Alm T (2012) Forekomstene av sibirnattfiol Lysiella oligantha på og rundt Sáhkkobátni i Alta (Finnmark). Blyttia 70: 250-254.

Alm T (2013) Statens veivesen - en miljøversting. Blyttia 71: 213-214. 
Andreassen J, Åsen PA (1980) Bidrag til floraen i Aust- og VestAgder (Agderherbariet, Kristiansand herbarium) - VI: Narrmarihand (Orchis morio) i Norge. Blyttia 38: 89-98.

Båtvik JI (1992) Sjeldne, sårbare og hensynskrevende karplanter i Østfold. Oversikt over utvalgte arter med lokalitetetsangivelser og litteraturrefereranser. Fylkesmannen i Østfold Miljøvernavdelingen Rapport 6/1992: 1-261.

Baugen T (2003) Narrmarihand Orchis morio - en kresen øyboer. Blyttia 61: 164-170.

Benum P (1958) The flora of Troms fylke. Tromsø Mus Skr 6: 1-402. Bjerke JW, Strann K-B (2009) Orkideen tettbrudespore Gymnadenia densiflora i Nord-Norge. Blyttia 67: 126-133.

Björkbäck F, Lundquist J (2005) Brunkullan (Nigritella nigra) i Jämtland och Härjedalen. Ekologi, populationsutvekling och skötselsaspekter. Slutrapport för 'Aktion Brunkulla'. Jämtland-Härjedalens Naturskyddsförbund, Världsnaturfonden (WWF).

Bjørndalen JE (1972) Om marisko og flueblom i Versvik, Eidanger. Årbok for Telemark 1972: 131-143.

Bjørndalen JE (1985) Some synchorological aspects of basiphilous pine forests in Fennoscandia. Vegetatio 59: 211-224.

Bjørndalen JE (1986) Kalktallskogar som naturvårdsobjekt i Sverige. Naturvårdsverket Rapport 3070: 1-180.

Bjørndalen JE (1987) Kalktallskogar på Gotland som naturvårdsobjekt. Länsstyrelsen i Gotlands län, naturvårdsfunktionen, Visby.

Bjørndalen JE (1988) Nedbygging av naturareal i et pressområde gjennom 15 år, belyst gjennom vegetasjonskart Grenland. UNIT-Vitenskapsmuseet Rapp Bot Ser 1988: 55-62.

Bjørndalen JE (ed) (1999) Biologisk mangfold i verneområder på Ringerike og i Kongsberg-Eikerområdet, Buskerud. Rapport Fylkesmannen i Buskerud Miljøvernavdelingen.

Bjørndalen JE (2003) Kalkgranskog i Sverige og Norge - förslag till växtsociologisk klassificering. Skogsstyrelsen Rapp 2003 8: $1-69$.

Bjørndalen JE (2005) Verneverdige edelløvskoger i Sogn og Fjordane - botanisk dokumentasjon. Rapport Fylkesmannen i Sogn og Fjordane Miljøvernavdelinga.

Bjørndalen JE (2006) Ophrys insectifera at the edge of its geographical range: aspects of ecology, vegetational affiliation and conservation in Norway. J Eur Orch 38: 415-448.

Bjørndalen JE, Brandrud TE (1989) Verneverdige kalkfuruskoger. Landsplan for verneverdige kalkfuruskoger og beslektede skogstyper i Norge. I Generell del. DN-rapport 1989: 1-148.

Brandrud TE, Bjørndalen JE (1985) Rike furuskoger i Norge. Blyttia 43: 114-120.

Bratli H, Myhre, A (1999) Vegetation - environment relationship of old hay meadows at Svervelid, Telemark, S Norway. Nord J Bot 19: 455-471.

Direktoratet for naturforvaltning (1999) Kartlegging av naturtyper. Verdisetting av biologisk mangfold. DN Håndbok 13.

Direktoratet for naturforvaltning (2006) Handlingsplan for rød skogfrue Cephalanthera rubra. DN Rapport 2006: 1-28.

Elvebakk A, Sortland A (1985) Botaniske undersøkingar av eit planlagt skytebaneområde i Bærdalen, Skibottsdalen, Storfjord kommune. Rapport Institutt for biologi og geologi, Universitetet i Tromsø.

Elven R (2007) Bakgrunn for endringer i Lids flora 2005. 4. Vassgrofamilien til grasfamilien. Blyttia 65: 238-254; 270-275.

Elven R, Fremstad E, Pedersen O (eds) (2013) Distribution maps of Norwegian vascular plants. IV. The eastern and northeastern element. Akademika forlag, Trondheim.

Engelskjøn T, Skifte O (1984) Forekomsten av svartkurle, Nigritella nigra, i Nordreisa, Troms. Blyttia 42: 138-142.
Fægri K (1960) Maps of distribution of Norwegian vascular plants. I. The coast plants. Oslo University Press.

Fægri K, Danielsen A (1996) Maps of distribution of Norwegian vascular plants. III. The southeastern element. Fagbokforlaget, Bergen.

Fremstad E (1997) Vegetasjonstyper i Norge. NINA Temahefte 12: $1-279$.

Fremstad E, Moen A (eds) (2001) Truete vegetasjonstyper i Norge. NTNU Vitenskapsmuseet Rapp Bot Ser 2001: 1-231.

Gärdenfors U (ed) (2005) Rödlistade arter i Sverige 2005. ArtDatabanken, SLU.

Gjærevoll O (ed) (1990) Maps of distribution of Norwegian vascular plants. II. Alpine plants. K norske Vitensk Selsk, Trondheim.

Halvorsen R, Andersen T, Blom HH, Elvebakk A, Elven R, Erikstad L, Gaarder G, Moen A, Mortensen PB, Norderhaug A, Nygaard K, Thorsnes T, Ødegaard F (2009) Naturtyper i Norge - Teoretisk grunnlag, prinsipper for inndeling og definisjoner. Naturtyper i Norge, versjon 1.0, Artikkel 1: 1-220.

Halvorsen R, Bryn A, Erikstad L, Lindgaard A (eds) (2015) Natur i Norge - NiN. Versjon 2.0.0. Artsdatabanken, Trondheim (http://www.artsdatabanken.no/nin).

Hanssen EW (1996) Rød skogfrue, Cephalanthera rubra, i Norge. Blyttia 54: 13-22.

Hanssen EW (1997) Myrflangre, Epipactis palustris, i Norge. Blyttia 56: 44-51.

Hanssen EW (2006) Rød skogfrue Cephalanthera rubra i Norge Nasjonal handlingsplan og oppfølging av denne. Blyttia 64: 251-256.

Hanssen EW (2011) Forslag til handlingsplan for myrflangre Epipactis palustris (L.) Crantz 2011-2015. Norsk Botanisk Forening Rapport 2011: 1-100.

Hedrén M (1999) Kommentarer om brunkullan och dess ursprung. Svensk Bot Tidskr 93: 145-151.

Hedrén M, Klein, E, Teppner H (2000) Evolution of polyploids in European orchid genus Nigritella: Evidence from allozym data. Phyton (Horn, Austria) 40: 239-275.

Hedrén M, Skrede S, Imsland S, Frøland T (2012) Systematisk posisjon av några norska Dactylorhiza - former. Blyttia 70: 139-155.

Henriksen S, Hilmo O (eds) (2015) Norsk rødliste for arter 2015. Artsdatabanken, Norge.

Høiland K (1990) Sibirnattfiol (Platanthera obtusata subspec. oligantha) - den forgjettede orkidé. Blyttia 48: 111-118.

Hoell GS (2011a) Myrflangre - forvaltning og utfordringer. Blyttia 69: $216-220$.

Hoell GS (2011b) Svartkurle Nigritella (Gymnadenia) nigra. Arbeid og status på noen lokaliteter i Hedmark og Oppland 2010. Norsk Botanisk Foreneing Rapport 2011: 1-56.

Hoell GS (2013) Rød skogfrue - prioritert art med funksjonsområde. Status basert på handlingsplanarbeidet 2006-2012. Norsk Botanisk Forening Rapport 2013: 1-32.

Hoell GS, Gustavsen SV, Skrede S (2011) Store primærforekomster av svartkurle Nigritella nigra i Kvikne, Tynset kommune. Blyttia 69: 20-28.

Holtan D, Grimstad KJ (2001) På jakt etter kvitkurle Pseudorchis albida ssp. albida på Sunnmøre. Blyttia 59: 22-30.

Hultén E, Fries M (1986) Atlas of North European vascular plants North of the Tropic of Cancer. I. Koeltz Scientific Books, Königstein.

IUCN (2008) Guidelines for using the IUCN red list categories and criteria. Version 7.0. Species Survival Commision, IUCN.

Johansen K (1991) Ny lokalitet for svartkurle - Nigritella nigra i Troms. Blyttia 49: 182. 
Kålås JA, Viken Å, Henriksen S, Skjelseth S (eds) (2010) The 2010 Norwegian Red List for species. Norwegian Biodiversity Information Centre, Norway.

Lid J, Lid DT (2005) Norsk flora. 7. utgåva ved Reidar Elven. Det norske samlaget, Oslo.

Lindgaard A, Henriksen S (eds) (2011) The 2011 Norwegian Red List for ecosystems and habitat types. Norwegian Biodiversity Information Centre, Norway.

Lundberg A (2013) Myrflangre Epipactis palustris gjenfunnet på Karmøy. Blyttia 71: 166-168.

Marker E (1969) A vegetation study of Langøya, southern Norway. Nytt Mag Bot 16: 15-44.

Miljødirektoratet (2013) Faggrunnlag for svartkurle Nigritella nigra. Oktober 2013.

Moen A (1990) The plant cover of the boreal uplands of Central Norway. I. Vegetation ecology of Sølendet nature reserve; haymaking fens and birch woodlands. Gunneria 63: 1-451.

Moen A, Øien D-I (2003) Ecology and survival of Nigritella nigra, a threatened orchid species in Scandinavia. Nord J Bot 22: 435-461.

Moen A, Øien D-I (2009) Svartkurle Nigritella nigra i Norge. Faglig innspill til nasjonal handlingsplan. NTNU Vitenskapsmuseet Rapp Bot Ser 2009: 1-27.

Moen A, Øien D-I (2012) Sølendet naturreservat i Røros: forskning, forvaltning og formidling gjennom 40 år. Bli med ut! 12: $1-103$.

Moen A, Wischmann F (1972) Verneverdige myrer i Oslo, Asker og Bærum. Rapport i forbindelse med den norske myrreservatplanen. K norske Vitensk Selsk Mus Miscellania 7: 1-70.

Mossberg B, Stenberg L (2003) Den nya nordiska floran. Wahlström and Widstrand, Stockholm.

Nordal I, Wischmann F (1986) Hvit skogfrue (Cephalanthera longifolia) i Norge. Blyttia 44: 10-14.

Nordal I, Wischmann, F (1987) Søstermarihand (Dactylorhiza sambucina) i Norge. Blyttia 45: 30-38.

Norderhaug, A, Bakkevik, B, Skogen, A (1997) Søstermarihand, Dactylorhiza sambucina, en truet art i Norge? Blyttia 55: 73-86.

Nordhagen R (1972) Dactylorhiza praetermissa (Druce) Hunt et Summerhayes, a marsh orchid new to Norway and adjacent parts of North Europe. Norw J Bot 19: 43-50.

Øien D-I, Moen A (2001) Nutrient limitation in boreal plant communities and species influenced by scything. Appl Veg Sci 4: 197-206.
Øien D-I, Moen A (2005) Plan for skjøtsel og forvaltning av leveområder for orkideen svartkurle (Nigritella nigra) sør for Sølendet, Røros. NTNU Vitenskapsmuseet Bot Notat 2005: 1-18.

Øien D-I, Moen A (2009) Sølendet naturreservat. Årsrapport og oversyn over aktivitetet 2008. NTNU Vitenskapsmuseet Bot Notat 2009: 1-37.

Økland RH (1984) Generelle aspekter ved utsatte plantearter i Vestfold fylke. Rapport til Fylkesmannen i Vestfold, Miljøvernavdelingen. Miljøverndepartementet Rapport T-579.

Pedersen O, Åsen PA (1994) Nasjonalt truete, sårbare og hensynskrevende karplanter (rødlistearter) i Aust-Agder. Rapport til Miljøvernavd., Fylkesmannen i Aust-Agder.

Riksrevisjonen (2006) Riksrevisjonens undersøkelse av myndighetenes arbeid med kartlegging og overvåkning av biologisk mangfold og forvaltning av verneområder. Dokument 3: 12 (2005-2006).

Rodriguez JP, Rodriquez-Clark KM, Baillie JEM, Ash N, Benson J, Boucher T, Brown C, Burgess ND, Collen B, Jennings M, Keith DA, Nicholson E, Revenga C, Reyers B, Rouget M, Smith T, Spalding M, Taber A, Walpole M, Zager I, Zamin T (2011) Establishing IUCN red list criteria for threatened ecosystems. Conserv Biol 25: 21-29.

Rønning OI (1954) The vegetation on the Ulmus glabra locality in Beiarn, northern Norway. Nytt Mag Bot 3: 197-202.

Røsok Ø, Hanssen EW, Abel K, Eid PM (2013) Myrflangre Epipactis palustris på Åbbortjernmyr i Asker, Akershus. En trist historie som kanskje ender godt. Blyttia 71: 157-166.

Schumacher T, Bendiksen E, Halvorsen R (1982) Sjeldne og sårbare plantearter i Sør-Norge. IV Knottblom (Malaxis monophylla). Blyttia 40: 85-93.

Sætra, H (1987) Svartkurle (Nigritella nigra) i Nordreisa - en underestimert forekomst. Blyttia 45: 93-95.

Skogen A, Odland A (1991) Flora og vegetasjon rundt Ervikvatnet, Stad 9 år etter senkingen, samt en vurdering av Morkadalsvassdragets botaniske verdi i verneplansammenheng. NINA Forskningsrapp 18: 1-60.

Skrede S (2001) Sannsynlig lokalitet for stormarihand Dactylorhiza praetermissa (Druce) Soó på Stadlandet. Blyttia 59: 32-36.

Teppner H, Klein E (1989) Gymnigritella runei spec. nova (Orchidacea-Orchidea) aus Schweden. Phyton (Horn, Austria) 29: 161-173.

Wischmann F (1989) Finnes stormarihand (Dactylorhiza praetermissa) i Norge? Blyttia 47: 175.

Wischmann F, Nordal I (1987) Exit Dactylorhiza pseudocordigera en antatt endemisme redusert. Blyttia 45: 129-135.

\section{Addendum}

The new Norwegian red list for species was published in November 2015 (Henriksen and Hilmo 2015), with the following changes in status: Anacamptis morio is upgraded to endangered (as recommended in the paper), Epipogium aphyllum upgraded to vulnerable and Coeloglossum viride spp. islandicum downgraded to endangered. Hammarbya paludosa is new with status near threatened. Neottia nidus-avis and Gymnadenia conopsea ssp. densiflora are omitted. 